ANNA BUŁA

Uniwersytet Łódzki

\title{
Rozwijanie myślenia krytycznego przez filozofowanie $z$ najmłodszymi uczniami
}

\author{
Myślenie jest zjawiskiem \\ naturalnym u czlowieka; nie jest nim \\ myślenie krytyczne. Jest to umiejętność, \\ która może być doskonalona
}

Wiek XX, bardzo często określany na gruncie nauk społecznych jako stulecie dziecka, nazywany jest także stuleciem raportów oświatowych, gdyż wiele krajów świata podjęło prace nad analizą swoich systemów edukacyjnych i w ich świetle dokonało ich weryfikacji i zbudowało koncepcje reform. Polska wzięła również udział $\mathrm{w}$ takich badaniach, których rezultaty zostały szeroko rozpowszechnione. Najpopularniejsze z nich to badania PISA ${ }^{2}$, z których wynika, że polscy uczniowie dobrze wypadaja $w$ zadaniach wymagających prostych umiejętności, np. odtwarzania informacji, a znacznie gorzej w rozwiązywaniu problemów, formułowaniu wniosków i sądów, myśleniu krytycznym, twórczym czy naukowym.

Dlatego, między innymi, coraz intensywniej w polskiej współczesnej literaturze pedagogicznej obecna jest problematyka rozwijania umiejętności myślenia u uczniów. Ta obecność wyraża się w postulowaniu kształcenia i doskonalenia zdolności i umiejętności myślowych dzieci oraz coraz skuteczniej projektowanych i realizowanych programach edukacyjnych skoncentrowanych na realizacji tych celów ${ }^{3}$.

${ }^{1}$ Cyt. za R. Pachocińki, Podstawy ksztatcenia wyższych umiejętności poznawczych w nowoczesnej szkole, Warszawa, 1998, s 86.

${ }^{2}$ Program Międzynarodowej Oceny Umiejętności Uczniów Organizacji Współpracy Gospodarczej i Rozwoju jest inicjatywą mającą na celu, przy pomocy cyklicznych badań, analizę skuteczności systemów edukacyjnych w krajach europejskich, należących do OECD oraz krajach niezrzeszonych.

${ }^{3}$ Klucz do uczenia się - Program rozwoju poznawczego oparty na pedagogice Lwa Wygotskiego, Szkoła z klasą - akcja organizowana przez „Gazetę Wyborczą” wraz z portalem gazeta.pl oraz Centrum Edukacji Obywatelskiej, Szkoła Myślenia - akcja zachęcająca nauczycieli do stosowania metod rozwijających myślenie, w tym uczniowskich projektów edukacyjnych, i inne. 
Jedną z takich inicjatyw jest propozycja, którą świat interesuje się już ponad 30 lat, a wiele szkół na świecie uczyniło z niej podstawowe narzędzie wychowywania i kształcenia młodego pokolenia, i która wciąż pilnie czeka na miejsce w polskiej szkole.

Filozofia dla dzieci sprawdziła się jako lekarstwo na biedę, wykluczenie społeczne, marazm i degradację $\mathrm{w}$ postaci zaaplikowanych szkołom $\mathrm{z}$ amerykańskich przedmieść i slumsów setek zajęć prowadzonych przez nauczycieli i jednocześnie doktorantów Matthew Lipmana, który w 1972 został profesorem filozofii w Montclair State College, a w 1974 dyrektorem Institute for the Advancement of Philosophy for Children w Montclair State College. Profesor Lipman, wychował bardzo liczne grono zwolenników nowoczesnej edukacji, także w Europie i mimo zaawansowanego już wieku stale jest aktywny w swojej dziedzinie i bezpośrednio udostępnia swoje doświadczenie i wiedzę przez nowoczesne media.

Uczniowie z tych szkół odzyskiwali wiarę w sens życia i wiarę we własne możliwości, budowali poczucie własnej wartości i rozbudzali swoje aspiracje, wielu z nich uratowało się przed narkotykami, przestępstwem i innymi przypadłościami czyhającymi na typowych mieszkańców enklaw biedy.

Ale także filozofia dla dzieci okazała się szalenie ciekawą propozycją kształcenia dla społeczeństw dobrobytu, poszukujących nowatorstwa i nowoczesnego podejścia do wychowanka, zgodnego $\mathrm{z}$ humanistyczną filozofią kształcenia, uwzględniającą indywiduum i podmiotowość ucznia, troszczącą się o jego dobro i pełnię rozwoju. Koncepcja ta uwzględnia założenia konstruktywizmu, w myśl którego wiedza wynika z własnego doświadczenia w konstruowaniu i rekonstruowaniu jej szczególnie za sprawą komunikacji z grupą społeczna.

Filozofia dla dzieci pilnie czeka na zaaplikowanie jej do polskiej szkoły, bo z jednej strony badacze i obserwatorzy rzeczywistości szkolnej wskazują na liczne jej niedostatki i upatrują źródeł naprawy jej w założeniach tego projektu edukacyjnego, a $\mathrm{z}$ drugiej strony pedagodzy i innowatorzy stale poszukuja pomysłów na nowoczesną polską szkołę.

Ważną cechą metody filozoficznych dyskusji jest jej atrakcyjność dla dzieci i młodzieży. Tworzenie w klasach wspólnot dociekających prowadzi do przekształcenia szkoły w miejsce przyjazne uczniowi.

Filozofia dla dzieci stanowi także wkład w rozwój filozofii, aby mogła ona funkcjonować jako rodzaj szczególnej edukacji, która odpowiada na podstawowe zapotrzebowanie dziecka, głodnego wiedzy i rozumienia ${ }^{4}$.

\footnotetext{
${ }^{4}$ Interview with Matthew Lipman-Part 1: The IAPC program/Part 2 by Saeed Naji. http://www.buf.no/en/read/txt/?page $=$ sn-lip

Saeed Naji is a researcher at the Institute for Humanities and Cultural Studies in Tehran, Iran, cfr. http://www.ihcs.ac.ir/. He also works as a journalist. In 2003 Saeed Naji interviewed Matthew Lipman, one of the founders of the modern philosophy for children-movement.
} 
Sądzę, że to, co odróżnia szkołę starą od tej nowej, którą staramy się w XXI wieku budować, kumuluje się między innymi w kompetencjach nauczyciela, który właśnie dziś ma szczególnie trudną rolę w przygotowaniu się do zawodu. Dlatego podkreślać należy, że nauczycielom pragnącym wykorzystywać tę metodę w przedszkolu i w szkole nie wystarczy typowe wykształcenie zawodowe i zaleca się im doskonalenie umożliwiające rozwijanie u siebie tych samych umiejętności, nad których rozwojem mają potem czuwać u uczniów. Ważne są w tym przypadku zarówno umiejętności intelektualne i te związane z procesem komunikacji jak i współpracy w grupie.

Autorzy polskiej wersji programu wyraźnie charakteryzują funkcje i zadania nauczyciela w takiej edukacji. Zadaniem nauczyciela nie jest przekazywanie wiedzy, lecz zachęcanie do myślenia, śledzenie procedur myślowych, pomoc w ich stosowaniu oraz ułatwianie procesów komunikacji w grupie. Nauczyciel nie modeluje treści filozoficznych pogladów uczniów i nie sprawdza ich zgodności z własnymi przekonaniami. Jego zadaniem jest doprowadzić do tego, by idee stworzone $i$ wypowiadane przez uczniów byty coraz staranniej i coraz bardziej wszechstronnie badane podczas dialogu. Nauczyciel ocenia rozwój umiejętności poznawczych uczniów i komunikacji $w$ grupie. Zadaniem nauczyciela jest stymulowanie rozwoju tych umiejętności, uważne obserwowanie tworzenia się wspólnoty dociekajacej oraz śledzenie indywidualnych postępów uczniów ${ }^{5}$.

Do najogólniejszych celów filozofowania z dziećmi należą:

Podtrzymywanie naturalnej ciekawości poznawczej dziecka opartej na potrzebie rozumienia świata, poprzez zadawanie pytań opartych o osobiste doświadczenia i zainteresowania.

Doskonalenie umiejętności samodzielnego myślenia. To, co odróżnia zajęcia prowadzone według programu Filozofia dla dzieci od innych zajęć szkolnych, gdzie dominującą rolę odgrywa przekazywanie treści, jest właśnie nastawienie na doskonalenie tych sprawności umysłowych, które pozwolą uczniom coraz skuteczniej zajmować postawę badawczą, co w rezultacie oznacza lepsze rozumienie otaczającego świata i skuteczniejsze komunikowanie się. Wśród celów adekwatnych dla dzieci w młodszym wieku szkolnym wskazać tu można:

- doskonalenie umiejętności myślowo-językowych, takich jak formułowanie pytań i problemów, stosowanie kryteriów, uzasadnianie, wyjaśnianie, klasyfi-

${ }^{5}$ B. Elwich, A. Łagodzka, B. Pytkowska-Kapulkin, Filozoficzne dociekania z dziećmi i młodzieżq - Opis programu edukacyjnego, Agencja Wydawniczo-Reklamowa, Halina Wodniak, Program nauczania pt. Filozoficzne dociekania z dziećmi i młodzieża przeznaczony dla I i II etapu edukacyjnego szkoły podstawowej oraz III etapu edukacyjnego gimnazjum został dopuszczony do użytku szkolnego na podstawie paragrafu 4 ust. 1 rozporzadzenia Ministra Edukacji Narodowej $z$ dn. 15 lutego 1999 r. w sprawie warunków i trybu dopuszczania do użytku szkolnego programów nauczania $z$ zakresu ksztatcenia ogólnego oraz warunków i trybu dopuszczania do użytku szkolnego podręczników i zalecania środków dydaktycznych, (Dz. U. Nr 14, poz. 130). 
kowanie, badanie założeń, wykrywanie sprzeczności, wnioskowanie, definiowanie, posługiwanie się przykładami itp.;

- przygotowanie do formułowania samodzielnych i przemyślanych sądów, będące efektem rozwijania wymienionych umiejętności, zetknięcia się z wielością i różnorodnością przekonań i poglądów na świat oraz krytyką i uzasadnianiem własnych i cudzych sądów;

- łączenie zdolności krytycznego i logicznego myślenia z umiejętnościami wyobrażeniowo-twórczymi.

Rozwój osobowy i spoteczny. Szczególnie dzieci rozwijają swoją zdolność porozumiewania się z innymi ludźmi. Nie tylko uczą się mówić, ale i słuchać tego, co mają do powiedzenia inne osoby oraz rozumieć ich myśli.

- rozwijanie umiejętności komunikacji, rozumianej jako zdolność jasnego wypowiadania się, słuchania i rozumienia innych oraz ustosunkowywania się do ich wypowiedzi;

- kształtowanie umiejętności współpracy w grupie, dialogu, postawy tolerancji i otwartości, które są warunkiem działania we współczesnym społeczeństwie ${ }^{6}$.

Zatem, po pierwsze w filozofii dla dzieci dba się o utrzymanie cenionej przez wszystkich ciekawości poznawczej dziecka, gdyż ta właśnie naturalnie w nim tkwiąca warunkuje jego rozwój. Małe dziecko bezustannie zdziwione jest światem, ale $\mathrm{z}$ wiekiem zyskuje taką o nim wiedzę i w taki sposób dostarczona, (przede wszystkim w szkole), że zdziwienie ustępuje miejsca znudzeniu. Już $w$ drugiej połowie lat pięćdziesiatych XX wieku Theodor W. Adorno, znany badacz spoteczeństwa, który wyrażat opinię, że jako dzieci wszyscy jesteśmy filozofami, równocześnie pesymistycznie zauważat, że przestajemy nimi być pod wptywem ksztatcenia, które uprzedmiotowiona $i$ podzielonq na poszczególne specjalności forma, wybija nam filozofię z głowy ${ }^{7}$. Także Karl Jaspers obwiniał konwencje, maski, opinie, sądy oczywiste świata dorosłych o uwięzienie i uśmiercanie dziecięcego geniuszu ciekawości ${ }^{8}$.

Dlatego nauczyciel powinien umieć dostrzegać różnicę miedzy dzieckiem znudzonym, niezainteresowanym, skazanym na bierność poznawczą, a dzieckiem aktywnym i ciekawym świata i na rzecz utrzymywania tego pożądanego stanu stosować właściwe strategie. Jednak, jakie i jak to robić: to jest ważne pytanie, na które nauczyciel $\mathrm{w}$ kształceniu akademickim $\mathrm{z}$ trudem znajduje odpowiedzi.

Kolejnym wskazanym tu postulatem jest rozwijanie myślenia, które według M. Lipmana jest procesem tak naturalnym jak oddychanie i trawienie, czymś, co wszyscy robimy. (...) Nawet $w$ najprostszej wymianie pytań $i$ odpowiedzi mamy

\footnotetext{
${ }^{6}$ Por. B. Elwich, A Łagodzka, R. Piłat, Filozofia dla dzieci. Informacja o programie, Warszawa 1996.

${ }^{7}$ M. Szczepska-Pustkowska, Dziecięce filozofowanie (i filozofowanie z dziećmi) jako zasada pracy z uczniem, „Kwartalnik Pedagogiczny” 2008, nr 1, s. 12.

${ }^{8}$ Tamże.
} 
do czynienia z ogromnq kondensacja aktywności umystu, spowodowanq wielkq ilościq myśli $i$ szybkościq pojedynczych procesów myślowych. Tak bardzo skupiamy uwage na wypowiedziach rozmówców $i$ własnych, że nie jesteśmy świadomi myślenia. (...) Dlatego skłonni jesteśmy sqdzić, że nie sposób je usprawnić, tak samo jak sqdzimy, by można byto doskonalić oddychanie czy trawienie. Zaktadamy niejako, że na ogót myślimy tak, jak można to robić najlepiej. (...) Niestety tak nie jest. Istnieja mniej i bardziej efektywne sposoby myślenia. (...) Nieprawidtowe wnioskowanie nie jest może myśleniem umiejętnym, tym niemniej jest to myślenie. Wyciagnięcie niewtaściwego wniosku, btędne definiowanie i klasyfikowanie, bezkrytyczne przyjmowanie faktów, wszystko to sq przypadki myślenia, jakkolwiek mamy tu do czynienia z myśleniem nieumiejętnym, niepoprawnym. Celem działań pedagogicznych - przynajmniej na poczqtkowym etapie procesu ksztatcenia - jest przemiana dziecka, które rozpoczynajac naukę szkolna jest już istota myślaca, w dziecko myślace poprawnie ${ }^{9}$.

Kryterium poprawności myślenia jest logika, jednak Lipman nie sugeruje uczenia logiki, by potrafić myśleć. Uważa, że już bardzo małe dzieci uczą się same logiki, ucząc się języka w sposób naturalny. „Reguty logiki tak jak reguty gramatyki przyswajaja sobie podczas nauki języka. Mówiqc małemu dziecku, „jeśli zrobisz to, zostaniesz ukarany, przyjmuje się, że zrozumie ono to zdanie w sposób następujacy: - jeśli nie chce zostać ukarany, nie powinienem tego robić. Nawet bardzo małe dziecko pojmuje, że do zaprzeczenia następnika, potrzebne jest zaprzeczenie poprzednika. Choć jest to dosyć wyrafinowany rodzaj rozumowania, dzieci potrafia je przeprowadzić w bardzo wczesnym okresie życia ${ }^{10}$.

Czym zatem objawia się poprawne i samodzielne myślenie dzieci w klasach początkowych? Jak je rozpoznawać, w jakich sytuacjach je obserwować, jak je stymulować, co uznać za osiągnięcie w dziedzinie samodzielności myślenia dziecka, a co nim jeszcze nie jest? Przez samodzielność w myśleniu rozumie się, za W. Okoniem właściwość myślenia ksztattująca się u ludzi wówczas, gdy swoje doświadczenie i swojq wiedze wzbogacaja przez rozwiazywanie zagadnień praktycznych $i$ teoretycznych. Tak rozumiana samodzielność w myśleniu ma szczególne znaczenie dla wychowania szkolnego. Nauczyciele ksztattuja ja wówczas, gdy systematycznie wdrażaja uczniów do formutowania problemów i poszukiwania pomystów ich rozwiazania, do rozwiazywania problemów i sprawdzania tych rozwiazań, wreszcie do poszukiwania zastosowań tych rozwiazań $w$ nowych sytuacjach. Ta praca nauczyciela ma zróżnicowany charakter: zależy od wieku uczniów, od przedmiotu nauczania oraz od stopnia osiagniętej już samodzielności. W poczatkowym jej etapie uczniowie rozwiazuja problemy prostsze $i$ tatwiejsze, stopniowo przechodzq do bardziej złożonych i trudnych, jednocześnie zaczynaja od rozwiazywania problemów postawionych

\footnotetext{
${ }^{9}$ M. Lipman, A. M. Sharp, F. S. Oscanyan, Filozofia w szkole, Warszawa 1996, s. 26.

${ }^{10}$ Tamże, s. 27.
} 
przez nauczyciela lub podręcznik, po czym stopniowo przechodzq do samodzielnego stawiania problemów $i$ weryfikacji ich rozwiazañ ${ }^{11}$. Zaś zgodnie z tym, co twierdzi M. Lipman, stan myślenia dzieci manifestuje się w mowie, ujawnia się w szczerych, spontanicznych wypowiedziach uczniów uczestniczących w dyskusji, która jest podstawową metodą prowadzenia zajęć. Dlatego pierwsze o co trzeba zadbać, to tworzyć w szkole takie sytuacje, w które dzieci chciałyby się zaangażować intelektualnie, żeby jak najczęściej używały języka, szczególnie żeby dyskutowały, rozmawiały ze sobą przynajmniej dwójkami, trójkami albo w większych grupach i traktować te rozmowy poważnie, to znaczy uważnie się im przysłuchiwać. Poprawne prowadzenie zajęć filozofowania wymaga również przyjęcia postawy uważnego $i \dot{z} y c z l i w e g o$ stuchacza, nienastawiajacego się na wychwytywanie btędów i potknięć językowych, ale starajacego się zrozumieć sens wypowiedzi oraz intencje mówiqcego ${ }^{12}$.

O samodzielności myślowej dziecka świadczą przede wszystkim jego zachowania werbalne. Wśród nich szczególne miejsce zajmują pytania dziecięce, co podkreślają wszyscy badacze aktywności poznawczej. Pytaniom w literaturze pedagogicznej poświęcono wiele miejsca. Jeśli chodzi o praktykę szkolną, to wyłania się dość jasno konkluzja, że w szkole za mało czasu i uwagi nauczyciele poświęcają pytaniom. Szczególnie dobitnie w tym kontekście brzmi konkluzja N. Postmana (...) cała wiedza, którq mamy, powstała w wyniku zadawania pytań, ta umiejętność jest najwyższym narzędziem intelektualnym człowieka. Czy to nie ciekawe zatem, że nie uczy się tego w szkotach (... $)^{13}$.

Nauczyciele prawie wcale nie zachęcają dzieci do wyrażania własnych zainteresowań poznawczych. Uwagę raczej koncentrują na dziecięcych odpowiedziach a raczej poprawności odpowiedzi na pytania stawiane przez siebie. Zwraca się uwagę na wiele nastawień i schematów w działaniach nauczycieli, należą do nich: dokładność i dosłowność reprodukcji informacji wymaganej od ucznia, ignorowanie problematyczności i kontekstualizacji sytuacji, nadawanie lub narzucanie jako niepodważalnych ${ }^{14}$. Tymczasem to właśnie pytania uczniów są probierzem tego, w jaki sposób dziecko uczestniczy w procesie kształcenia. Jeśli dziecko uważnie słucha innych, na przykład nauczyciela, to doskonale wie, kiedy czegoś nie rozumie, albo bardzo je coś intryguje i wtedy po prostu pyta.

W filozofii dla dzieci jest przynajmniej kilka momentów, w których jest miejsce na pytania uczniów. Pierwszy moment występuje wtedy, gdy inicjowane jest zajęcie, prezentowany czynnik wywołujący dziecięce zainteresowanie, np. czytamy tekst, prezentujemy jakiś inny wytwór kultury, albo odwołujemy się do

${ }^{11}$ W. Okoń, Stownik pedagogiczny, Warszawa 1981, s. 268.

${ }^{12}$ H. Diduszko, Filozofowanie z dziećmi, www.scenamysli.eu, 2010, nr 2.

${ }^{13}$ Cyt. za I. Czaja-Chudyba, Rozwijanie myślenia krytycznego u dzieci powinnościq wspótczesnej edukacji, [w:] B. Muchacka (red.), Szkoła w nauce i praktyce edukacyjnej, t. 2, Kraków 2006, s. 296.

${ }^{14}$ Tamże. 
jakiegoś momentu wspólnie przeżytej rzeczywistości i po prostu pytamy dzieci, czy w treści danej prezentacji znalazło się coś, co je bardzo zdziwiło, zainteresowało, zaintrygowało. Nie wszystkie dzieci potrafią od razu zadawać mądre, dobre, dociekliwe pytania. Wiemy, że dzieci w tej materii mają wielki potencjał, ujawniający się $\mathrm{w}$ bardzo wczesnym dzieciństwie, ale wiemy też, że przez pierwsze lata swojego życia są skutecznie przez rodziców, nauczycieli i innych wychowawców pozbawiane złudzeń, co do wartości takiego zapytywania. Szybko też za sprawą działań pedagogicznych dowiadują się, że rolę pytającego ma dorosły. Ponieważ dorosły jest kimś strasznie ważnym w świecie dziecka, autorytatywnie przyjmują też, że pytania mają jakąś swoją odpowiedź, którą zna dorosły, a rolą dziecka jest poznać taką właśnie odpowiedź. Tymczasem w filozofii dla dzieci rzecz ma się zupełnie odmiennie. Toteż dzieci, zanim odkryją swoją rolę $w$ takiej edukacji formułują wiele pytań tak, żeby pasowały do świata, jakiego zaznały, często naśladują swojego nauczyciela. Nie wiedziałabym tego, gdyby nie okazja do rozmów o jakości pytań dziecięcych na zajęciach z filozofowania, jakie odbywałam z moimi studentkami a jednocześnie nauczycielkami, które zachęciłam do takiej pracy z dziećmi. Początkowo prawdziwa praca $\mathrm{z}$ wykorzystaniem metody M. Lipmana nie przynosiła im satysfakcji, bo jak spostrzegły, dzieci zadawały zbyt dużo nieciekawych, infantylnych pytań. Przyglądałyśmy sie przykładom tych pytań, zastanawiałyśmy się, co to znaczy, że pytanie dziecka jest nieciekawe, infantylne i dochodziłyśmy do wniosku, że dzieci trzymają się wyuczonego wcześniej schematu, narzuconego przez nauczyciela. To potwierdza kolejny fakt, że dzieci są bardzo wnikliwymi, bystrymi obserwatorami świata i widzą to, o co nawet ich nie podejrzewamy. Zatem dzieci zadawały pytania o sprawy, które były wprost opisane w tekście, były oczywiste i ewentualna dyskusja zawsze skazana była na niepowodzenie, bo wcześniej czy później już nie było o co się spierać. W filozofii dla dzieci zajmowanie się jakimś tekstem na zajęciach wcale nie służy poznaniu tego, co napisano w tym tekście, o czym on jest - jak to zazwyczaj ma miejsce w praktyce szkolnej, ale na poznaniu tego, czego tam nie napisano wprost. Jednak wszyscy i dzieci i nauczyciele musimy po pierwsze to zaakceptować, a po drugie cierpliwie uczyć się tego nawzajem.

Zatem w filozofowaniu z dziećmi chodzi o to, by zachęcać dzieci do zadawania pytań, na które nie można nic pewnego odpowiedzieć a jedynie przypuszczać odpowiedzi i starać się docierać do jak najpełniejszych. Dlatego często na zajęciach dzieci przyglądają się (precyzują, porównują, grupują, przekształcaja) swoim wytworom (pytaniom), które nauczyciel zawsze wszystkie jakoś utrwala - nagrywa, spisuje, rysuje - bez swoich subiektywnych ocen. Wszystkie, bowiem stanowią wartość dla procesu uczenia się. W konsekwencji uczniowie dochodzą do wprawy $w$ formułowaniu najlepszych pytań. Uczniowie mają potem okazje przekonywać się, że im lepiej sformułowane pytanie badawcze tym ciekawszą odbywa się dyskusję, tym bardziej zagorzałe spory można toczyć. Także wyczuwając jakość postawionego pytania, dzieci troszczą się 
o nie dość długo. Wiem to, bo moi uczniowie wielokrotnie podchodzili do mnie długo po zajęciach, komunikując - Prosze pani, ja nawet nie mogłam spać, bo o tym ciagle myślatam.... Prosze pani, a ja $w$ niedziele zadatem nasze pytanie mamie..., Prosze pani ja sktadam raport $z$ ferii, bo nad naszym pytaniem sie $w$ ferie zastanawiatem.

Drugi moment, w którym metoda ta jest otwarta na dziecięce pytania to czas dyskusji. Tutaj toczą się spory o ważne dla dzieci sprawy i zawsze każde może pytać, jeśli nie rozumie czyjejś wypowiedzi, czyjegoś argumentu. W trakcie dziecięcych dyskusji niejednokrotnie miałam okazje zaobserwować następujące pytania, świadczące o dociekliwości i samodzielności myślowej-Skqqd wiesz, że tak..., A skad możemy być pewni, że..., Kto się ze mna zgadza?

Dyskusja, w którą zaangażowane są dzieci sprzyja rozwijaniu się szczególnej umiejętności myślenia, jaką jest myślenie krytyczne. Tu kładzie się nacisk na rozwój krytycznego myślenia przez zapytywanie, dociekliwość i dialog przede wszystkim między uczniami. Filozofia dla dzieci wzmacnia umiejętności komunikacyjne oraz kształtuje nawyki inteligentnego zachowania, do których zalicza się

- ciekawość - przez zadawanie ciekawych poznawczo pytań

- współpracę - przez zaangażowanie w dyskusję

- krytyczność - przez poszukiwanie przyczyn i dowodów

- kreatywność - przez kreowanie i konstruowanie idei

- staranność - przez rozwijanie samoświadomości i troszczenie się o innych ${ }^{15}$.

Obecnie panuje powszechna zgodność, co do wartości takiego myślenia we współczesnym demokratycznym świecie, jednak jeszcze niezbyt powszechnie wierzy się, że może być przedmiotem nauczania w szkole. Przegląd literatury pokazuje jak trudno jest ustalić, co to jest w ogóle myślenie krytyczne i jakie mogą być skuteczne sposoby nauczania tej umiejętności w szkole. W wyjątkowo trudnej sytuacji jest polski nauczyciel, a szczególnie nauczyciel wczesnej edukacji, który właściwie tylko w języku obcym - angielskim, francuskim, niemieckim znajduje konkretne wskazówki dydaktyczne.

Wśród cech wyróżniających człowieka myślącego krytycznie należy wymienić ciekawość intelektualną, obiektywność, opierającą się na rozpatrywaniu dowodów bez uprzedzeń i osobistych niechęci, otwartość na szerokie spektrum informacji, giętkość, czyli gotowość na zmiany poglądów, sceptycyzm i uczciwość intelektualną, systematyczność, upór w dążeniu do celu, zdecydowanie i szacunek dla opinii i poglądów innych ${ }^{16}$. Sam nauczyciel powinien pielęgnować w sobie te cechy.

${ }^{15}$ R. Fisher, Talking to Think, in D. Jones \& P. Hodson (eds), Unlocking and Listening London: David Fulton, 2006.

${ }^{16}$ R. Pachocińki, Podstawy kształcenia wyższych umiejętności poznawczych w nowoczesnej szkole, Warszawa 1998, s. 89-91. 
Sądzi się obecnie, że myślenie krytyczne stanowi formę inteligencji, której można nauczyć (nie jest właściwością niezmienna) a myślenie o myśleniu, jest głównym elementem krytycznego myślenia. Przede wszystkim jednak oznacza świadomość, dyscyplinę myślenia, zmierzającą do permanentnego podnoszenia jego jakości, walkę z egocentrycznymi lub socjocentrycznymi tendencjami, zmianę stylu życia na bardziej racjonalny i empatyczny jednocześnie. Wiedza krytyczna $i$ umiejętność myślenia krytycznego jest produktem uczenia sie $i$ treningu. To nic innego jak intelektualny nawyk $i$ zarazem siła. To podstawowa cecha człowieczeństwa, w której tak samo kobiety jak i mężczyźni powinni być ćwiczeni. To jedyna broń przeciwko złudzeniom, kłamstwom, przesqdom oraz btędnemu mniemaniu o sobie samym i swojej ludzkiej egzystencji. Edukacja jest dobra wtedy zawsze, gdy kreuje ludzi śmiało myślacych, rozwijajacych krytyczne spojrzenie na świat, niebojacych sie dociekać. Nauczyciel jakiegokolwiek przedmiotu, który kładzie nacisk na rozumowanie, poszukiwanie dowodów, weryfikacje $i$ powtarzanie kultywuje te metode $i$ pozwala $w$ tym samym momencie swoim uczniom na wyrobienie sobie nawyku krytycznego myślenia. Człowiek poddany takiemu typowi ksztatcenia nie jest jednostka przeciętna, nie można mu przylepić etykiety. Człowiek taki, jeśli wyćwiczony, jest cierpliwy w poszukiwaniach $i$ stały wobec idei krytyczności. Dtugo waży on dowody i umie być ponad wszechobecnymi stereotypami. Ksztatcenie $w$ krytycznym myśleniu jest jedynym sposobem, o którym można szczerze powiedzieć, że kreuje dobrych obywateli ${ }^{17}$.

Lipman odróżnia myślenie krytyczne od zwykłego. To drugie jest proste i brakuje mu kryteriów. Myślenie krytyczne jest bardziej złożone i opiera się na kryteriach obiektywności, użyteczności i logiki. Dlatego zadania stawiane przez nauczyciela powinny przybierać kierunek:

- od zgadywania do szacowania

- od wybierania do oceniania

- od grupowania do klasyfikowania

- od wierzenia do przypuszczenia

- od luźnych wniosków do wnioskowania logicznego

- od taczenia pojęć do wychwycenia zasad

- od zauważenia zależności do zauważenia zależności między zależnościami

- od przypuszczeń do hipotez

- od wyrażenia opinii bez uzasadnienia do wyrażania opinii uzasadnionych

- od wyrażenia sadów nie opartych na kryteriach do wyrażenia sqdów opartych na kryteriach ${ }^{18}$.

${ }^{17}$ Frank J. McVeigh, Brief History of Social Problems: A Critical Thinking Approach, University Press of America 2004, http://www.criticalthinking.org/page.cfm? 8, The Critical Thinking Community, Glossary of Critical Terms.

${ }^{18}$ E. Kordylas, M Pęziak, Rozwój zdolności myślenia, http://www.profesor.pl/. 
W świetle przytoczonych treści można wyłonić z nich dwie podstawowe cechy krytycznego myślenia. Brzmią one następująco:

- krytyczne myślenie to nie tylko rodzaj rozumowania, ale myślenie, które zakłada samodoskonalenie;

- samodoskonalenie to ma swoje źródło w ludzkiej umiejętności poprawnego oceniania jakości myślenia ${ }^{19}$.

Badacze tacy jak L. Elder oraz R. Paul twierdzą, że wyraźne, namacalne zyski ptynqce $z$ wdrażania uczniów $w$ krytyczne myślenie nie zostanq osiagnięte póki nauczyciele nie zrozumieja tego, że umiejętne krytyczne myślenie przechodzi przez przewidywalne stadia rozwoju, które musza być tak samo wspierane jak całość tej umiejętności $i^{20}$.

Należy przede wszystkim, za badaczami, przedstawić główne założenia rozwoju myślenia krytycznego.

- istnieją przewidywalne stadia rozwoju myślenia krytycznego, przez które przechodzi osoba doskonaląca krytyczne myślenie;

- rozwój krytycznego myślenia nie następuje automatycznie i nie jest nieświadomy, przeciwnie, zakłada on, dla przejścia w kolejną jego fazę, poświęcenie i trening;

- sukces w nauczaniu jest ściśle powiązany z jakością myślenia uczniów;

- w rozwoju myślenia krytycznego może (jest możliwe) pojawić się regres, czyli cofanie się ${ }^{21}$.

Istnieje, zatem potrzeba, aby wymienić i scharakteryzować kolejne etapy rozwoju krytycznego myślenia. Każda faza rozwoju myślenia krytycznego nosi przyporządkowaną sobie nazwę. Są to kolejno:

- Stopień pierwszy: Myśliciel Nierefleksyjny; wysoce nieświadomy tego, jak ważną rolę w jego istnieniu gra mechanizm myślenia. Skutkuje to pojawieniem się w codziennej egzystencji wielu niepotrzebnych problemów. Myśliciele cierpiący na brak refleksji nie umieją prawidłowo oszacować jakości swojego rozumowania, skutkiem czego ludzie ci myślenia nie doskonalą. Myśliciele Nierefleksyjni mogą rozwijać w sobie szereg operacji umysłowych, nawet osiagnąć w nich wysoki poziom, jednak nie są świadomi ani jakości tego mechanizmu, ani stopnia rozwoju własnych funkcji intelektualnych.

- Stopień drugi: Myśliciel Kwestionujacy; zaczyna zauważać i zastanawiać się nad istotną rolą, jaką gra w jego życiu myślenie. Zdaje sobie sprawę, że jego myślenie jest często zawodne, błędne, jednakże nie jest w stanie zidentyfikować większości tych omyłek. Fundamentalną cechą tego etapu myślenia powinna być intelektualna pokora i skromność, która pozwala zauważyć

${ }^{19}$ http://www.criticalthinking.org/aboutCT/CTquestionsAnswers.cfm, Richard Paul, Critical Thinking: Basic Questions \& Answers, tłumaczenie własne.

${ }^{20} \mathrm{http} / / /$ www.criticalthinking.org/articles/ct-development-a-stage-theory.cfm, Linda Elder with Richard Paul, Critical Thinking Development. A Stage Theory.

${ }^{21}$ Tamże. 
sytuacje, kiedy to trudności mają źródło właśnie w samym myśleniu. Należy wykorzystać fakt, że uczniowie na tym etapie myślenia podjęli już rozważania na temat jego jakości.

- Stopień trzeci: Myśliciel Poczatkujacy; jest zainteresowany istotą i mechanizmem myślenia, wie, że procesy umysłowe w nim zachodzące zawierają wiele błędów oraz wyraża chęć doskonalenia swojego rozumowania. Człowiek na tym szczeblu myślenia nie tylko wie, że istnieją standardy wobec oceniania rozumowania danej jednostki, takie jak: klarowność, trafność, logiczność, ale umie on także przenieść je z płaszczyzny teoretycznej wiedzy na praktykę w codziennym działaniu, jest w stanie przyjąć zewnętrzną krytykę dotyczącą jakości własnego myślenia. Ma on wystarczająco dużo umiejętności, by rozpoczać proces monitoringu pracy swojego umysłu, jednakże jeszcze na tym etapie, podejmuje taką kontrolę sporadycznie. Podejmuje też próby szacowania jakości rozumowania innych ludzi. Wyzwaniem dla nauczyciela, jest utwierdzenie uczniów swoich w przekonaniu, iż każdy z nas, jeśli chce się doskonalić, potrzebuje systematycznego ambitnego treningu.

- Stopień czwarty: Myśliciel Praktykujacy; ma poczucie jak wiele pracy musi włożyć w toku dalszego doskonalenia się. Wypracował on już w sobie nawyk monitorowania pracy własnego umysłu oraz kontrolowania jakości podejmowanych przez siebie działań umysłowych. Jednostka taka wie nie tylko, że pewne problemy mają źródło w ludzkim umyśle, ale jest świadoma także, że aby je rozwiązać, należy traktować je globalnie i systematycznie. Myśliciel ten wie także, iż ludzki umysł ma tendencję do tworzenia szeregu złudzeń, ulegania stereotypom oraz wypracowywania błędnych, nieobiektywnych,

- Stopień piąty: Myśliciel Zaawansowany; zaczyna odkrywać to, co było do tej pory nieznane, sięga on powoli, nieśmiało w głębię swojego rozumu, do struktur, które wcześniej pozostawały nietknięte, ma dość dobrze opracowany harmonogram ulepszania mechanizmu własnego myślenia, wprowadza on go w codzienność intensywnie trenując. To stadium zezwala także na coraz śmielsze posługiwanie się kryteriami oceny wartości własnego toku rozumowania, sprawdzanie jego logiczności, trafności, badanie kompleksowości. Postępowanie takie może dotyczyć również sposobu rozumowania innych ludzi wokół Myśliciela Zaawansowanego. Coraz mniej zagadnień jest już pozostawianych bez zainteresowania, zaniedbywanych. Myśliciel Zaawansowany ma dostateczne zdolności, by poddawać krytyce własny plan treningu w rozumowaniu oraz, aby oceniać jakość swojego myślenia. Wskazanie na mocne i słabe strony pracy swojego umysłu nie stanowi już trudności,

- Stopień szósty: Myśliciel Mistrz; posiada nawyk samokontroli mechanizmu myślenia dotyczącego tak wyjątkowych jak i codziennych sfer życia jednostki ludzkiej, która wie już, że wiele spośród problemów ma swoje źródło właśnie w zaburzonej pracy operacji intelektualnych. Za nadrzędny cel, w tym sposobie rozumienia etapu, uważa się podtrzymanie tego, co już zostało osiagnnięte. 
Wiadomo bowiem, że w przypadku umiejętności myślenia krytycznego możliwy jest regres. Celem może być także ciągłe poszukiwanie tych sfer, które można by ulepszyć. Jest dostatecznie biegły i profesjonalny w myśleniu, aby poddawać je kontroli pod względem logiczności, trafności i kompleksowości. Mistrz wnioskuje, buduje pojęcia, stawia hipotezy, szacuje i jest w stanie skutecznie przeciwstawić się stereotypom. Siła a zarazem zagrożenie w tej fazie polega na przekonaniu, iż jest to etap ostateczny ${ }^{22}$.

Poniżej prezentuję stenogram zajęcia ${ }^{23}$, jakie zorganizowałam dla uczniów klas drugich szkoły podstawowej w ramach specjalnych zajęć prowadzonych zgodnie z metodyką M. Lipmana, których celem było zainicjowanie dziecięcej refleksji o własnym myśleniu. Sądzę, że jest to jeden z pierwszych kroków, jakie musi postawić dziecko $\mathrm{w}$ drodze przez omówione wyżej etapy własnego rozwoju.

\section{Temat: JAK MYŚLIMY}

Cele: podstawowym celem jest zachęcenie do wysiłku intelektualnego poprzez ciekawe zadania i zwrócenie dziecięcej uwagi na proces myślenia, jako zjawisko, które występuje u wszystkich ludzi i u nich też. Dzieci powinny mieć okazje do uświadamiania sobie myślenia i w konsekwencji kontrolowania swojego myślenia.

\section{Stenogram zajęć}

Na poprzednich zajęciach zastanawialiśmy się, jaki jest filozof, tzn. co mu jest bardzo potrzebne, żeby mógł być filozofem. Dzieci bez wahania powiedziały, że głowa, bo właśnie od niej zależy czy się będzie filozofem. Dalej ustalono konieczność narysowania ręki podpierającej głowę, bo to podpieranie pomaga myśleć ${ }^{24}$.

Myśli filozofa są w jego głowie, a ściślej w mózgu, który narysowaliśmy. Oprócz myśli, zdaniem dzieci, w mózgu jest pamięć i pomysły. Zupełnie bez problemu dzieci zrezygnowały z okularów, jako atrybutu filozofa, ale uznały, że oczy, nos i uszy są mu bardzo potrzebne. Najwięcej sporu wywołała broda i włosy. Broda nie miała być tutaj symbolem dojrzałości czy nawet starości, zwykle nierozerwalnie kojarzonej z doświadczeniem i mądrością, co raczej symbolem męskości. Podobnie jak krótkie włosy. Spór dzieci, wyrażający charakterystyczny w tym wieku konflikt płci, rozgorzał. Powstał portret filozofa

${ }^{22} \mathrm{http} / / /$ www.criticalthinking.org/articles/ct-development-a-stage-theory.cfm, Linda Elder with Richard Paul, Critical Thinking Development. A Stage Theory. Skrót thumaczenia pochodzi z pracy magisterskiej Emilii Olszówki, napisanej pod kierunkiem dr Anny Buły w Katedrze Pedagogiki Przedszkolnej i Wczesnoszkolnej UŁ.

${ }^{23}$ Zapis przebiegu zajęć, dyskusji dzieci.

${ }^{24} \mathrm{Na}$ poprzednich zajęciach wystąpił ciekawy moment, który wykorzystałam jako punkt wyjścia do rozmowy. 
z częścią włosów krótkich a częścią długich, ale nie zadowolił on moich myślicieli.

Zatem zajęcia zaczęły się właśnie od przypomnienia tego sporu. Zadałam pytanie $^{25}$ :

- Dlaczego niektórzy z was uważają, że tylko chłopcy mogą być filozofami?

- Bo chtopcy więcej myśla i sq madrzejsi..

- A jak przekonać się, że więcej myślą?

- No, bo myśla o sporcie, o samochodach.... No i o różnych rzeczach.

- No wtaśnie, bo chtopaki to tylko o tym myśla.

- A skąd wiesz, że tylko o tym, może my myślimy jeszcze o rodzinie?

- No a skad wiesz, o czym myśla dziewczyny, może też o samochodach?

Lodołamacz: rysowanie własnych myśli ${ }^{26}$.

Przerwałam ten emocjonujący dialog, prosząc o narysowanie tego, co w tej chwili myślimy. Dzieci zabrały się do pracy. Powstały różne rysunki. Dziewczynki rysowały siebie w różnych sytuacjach - jak się uczą, jak zdobywają puchar, jak tańczą, narysowały marzenie o piesku, o ubraniu mamy, w którym przyjdzie dziś do szkoły, o fajnej szkole. Chłopcy natomiast narysowali dinozaury (4rysunki), Harry`ego Pottera , Ufoludka i swoją siostrę. Zebraliśmy rysunki na wystawkę, dzieci zaprezentowały ich treść i zastanawialiśmy się, czy te narysowane myśli da się jakoś poukładać. Zasugerowałam, że może da się je poukładać w jakieś grupy. W efekcie utworzyliśmy:

- Grupe myśli o ludziach i grupę myśli o zwierzętach. Jeden rysunek nie pasował do żadnej grupy, bo przedstawiał szkołę. Autorka zaznaczyła, że właściwie może on pasować do grupy rysunków z ludźmi, bo przecież do szkoły chodzą ludzie;

- Grupę myśli o żywych „rzeczach”(Harry Potter, dinozaury i Ufoludek są przecież żywe) i jednoelementową grupę o rzeczach nieżywych;

- Grupę myśli o rzeczach, które wiemy, że są i grupę myśli o rzeczach, które wiemy, że kiedyś były.

${ }^{25}$ Szczególnie w pierwszych zajęciach polecam stawianie pytań przez nauczyciela. Stanowią one swoisty wzorzec dla dzieci. Jednocześni uczulają, uwrażliwiają dzieci na znaczenie własnych wypowiedzi, bo właśnie te pierwsze pytania stawiane przez nauczyciela często wypływają z kontekstu dziecięcej rozmowy.

${ }^{26} \mathrm{Na}$ tych zajęciach dzieci często rysują. Przekonałam się, że niektóre dzieci nie zaczynają rysowania, dopóki nie zobaczą, co rysuje kolega, i wtedy z reguły rysują to samo lub coś b. podobnego. Ponieważ te rysunki bywają wykorzystywane do dalszej pracy, warto zadbać, by nie były jednakowe, dlatego wszelkimi sposobami tworzę warunki do powstania indywidualnych dzieł (zachęcam, proponuję zająć dogodne miejsce, w dowolnej części sali. Z czasem dzieci zaczynają być dumne ze swoich oryginalnych prac i same do tego dążą. Warto czasem pochwalić kogoś za oryginalność, wyjątkowość). 
Po tej pracy przyszła pora na dyskusję ${ }^{27}$.

- Czy spróbujecie zastanowić się, jak to się dzieje, że człowiek myśli?

- No jak ma mózg i oczy to może myśleć.

- Ja się z nim zgadzam.

- To ciekawe, co mówicie, ale dlaczego oczy, waszym zdaniem, są potrzebne do myślenia.

- No, bo oczy widza do góry nogami i mózg to odwraca, a tak to by nie wiedziat, co ma odwracać. Najwyżej cztowiek musiałby stać cały czas do góry nogami, to by oczy widziaty odwrotnie i by byto lepiej.

- Czy to znaczy, że gdy mamy zamknięte oczy to nasz mózg ma wolne, nie musi niczego odwracać, nie musi myśleć?

- No musi, ale o czymś innym.

- Czyli to znaczy, że żeby myśleć nie trzeba widzieć?

- No, ale to trzeba chociaż styszeć.

- Albo węchać ${ }^{28}$ albo dotknać.

- I na pewno nie da się myśleć, jeśli się nie czuje, nie widzi i nie słyszy?

- No da się, bo nawet takie dzieci, co jeszcze się nie urodzq już myśla.

- A co myśla takie dzieci?

- Chyba o tym jak jest w środku, w brzuszku u mamy.

- Prosze pani ja myśle, że myśleć można o tym, co się zna. Nie myślimy o tych rzeczach, o których jeszcze nie wiemy?

- To nie jest prawda, bo ktoś coś wymyśli, a tego jeszcze nie ma, tylko to potem się nazwie i o tym innym ludziom powie, ale najpierw tego się nie zna a sie wymyśli ${ }^{29}$.

Na kolejnych zajęciach przeczytałam dzieciom zapisane fragmenty ich dyskusji. Głównie po to, żeby wszyscy mieli okazję usłyszeć te ostatnie kwestie. Chciałam też powiedzieć dzieciom, jak one mi się podobają, bo właśnie pokazują, że jedno dziecko wyraża swój ciekawy pogląd, a drugie się z nim nie zgadza. I że właśnie filozofowanie polega na poznawaniu swoich poglądów. Słuchały z zaciekawieniem wyraźnie ucieszone, że rozpoznają w tym tekście swoje własne słowa.

- A może ktoś z was ma jeszcze ochotę powiedzieć, jaki jest jego pogląd? Czy zgadza się z tym, co mówi Ola, że myśleć można o tym, co się zna?

\footnotetext{
${ }^{27}$ Ta dyskusja jest także inspirowana nauczycielskim pytaniem.

${ }^{28}$ Jako nauczyciel powinnam poprawiać takie błędy, ale charakter tych zajęć prowokuje mnie czasami do wyjątku. Wielokrotnie bowiem straciliśmy wątek, natchnienie po mojej korekcie jakiejś pięknie niezgrabnej wypowiedzi dziecka. Tu raczej zachodzi potrzeba ustalenia, co znaczy to, co mówi dziecko, a nie jak to poprawnie powinno brzmieć. Zresztą, dzieci z czasem nabywają precyzji i poprawności wypowiedzi.

${ }^{29}$ Wytłuściłam moim zdaniem bardzo ważną i interesującą wypowiedź dzieci i już wiem, że na to czekałam. Cel, który postawiłam wydaje się być możliwy do osiagnięcia.
} 
- Nie, ja uważam, że myśleć można i tym, co się jeszcze nie zna. Na przykład jak utytułować scenę z filmu jak reżyser jeszcze nie wie. To trzeba to wymyślić.

- Jak rozumiem chcesz powiedzieć, że reżyser wymyśla różne rzeczy. Ale czy to znaczy, że myśli o rzeczach, których nie zna?

- No wymyślanie to jest taki rodzaj myślenia.

- To bardzo ciekawe, czy moglibyśmy zastanowić się czy oprócz wymyślania są jeszcze inne rodzaje myślenia?

Tu nastąpiła wspólna narada z rysowaniem tego, co dzieci mówiły. Ustaliliśmy, że jest kilka rodzajów myślenia. Ola znów powiedziała coś ciekawego.

- Proszę pani, jak ja myśle, to myślenie przeksztatca się w zastanawianie.

- A czym Olu różni się twoje zastanawianie od tego myślenia, które było przed nim?

- No, bo jak widze jakiś obraz, to już nie myślę, co widze, tylko zastanawiam się, kto go namalowat, skad on tutaj się wziat?

- Czy zgadzacie się, żebyśmy zastanawianie się uznali za odmianę myślenia?

- Taaaaak

- Czy wyczerpaliśmy już nasz problem? Czy wymyślanie i zastanawianie to wszystkie rodzaje myślenia?

- Nie, pomysty to też myślenie.

- Coś ty, pomysty to przecież jest wymyślanie!

- No wtaśnie.

- Dobrze, zapiszemy pomysły przy wymyślaniu.

- Ale jak architekt coś chce zaprojektować, to musi wymyślać i to musi zaplanować.

- Czy chcesz powiedzieć, że planowanie to rodzaj myślenia, co sądzicie o tym?

- No tak, jak się planuje, to się myśli. Niech pani to zapisze.

- A jak się ma fatamorganę, to też się myśli, tylko, że tego nie ma.

- No fatamorgana jest na pustyni: widzisz drzewa a ich nie ma, ale ty myślisz, że one sq.

- Jak nazwiemy to myślenie o drzewach, których nie ma?

- No bo sobie to wyobrażamy.

- Czy chcecie powiedzieć, że wyobrażanie sobie czegoś to też jest rodzaj myślenia?

- Tak i ja mam jeszcze jeden pomyst. Też jest takie wyobrażanie jak się śni, tylko, że się wtedy śpi i nie wie się, że się myśli.

- Czy zapiszemy, że według was rodzajem myślenia jest śnienie?

- A odkrycie dinozaurów to teżjest myślenie, jakby nikt o tym nie myślat, to nikt by nie wiedziat, że dinozaury byty.

- Czy to znaczy, że mamy jeszcze jeden rodzaj myślenia? A czym się różni odkrywanie od np. wyobrażania albo od zastanawiania? 
- No bo wyobrażamy sobie coś, czego nie ma, a dinozaury tak naprawdę byty, a jak się zastanawiamy, to wiemy nad czym się zastanawiamy, a przecieżjak coś odkrywamy, to nie wiemy, co odkryjemy.

- Przekonałeś mnie, zapisuję, że odkrywanie to rodzaj myślenia.

\section{Podsumowanie}

Przed dziećmi leży arkusz papieru, na którym zapisywaliśmy propozycje. Zapisywał nauczyciel w postaci drzewka.

- Czy ktoś potrafiłby podsumować efekty naszej pracy? ${ }^{30}$

- Dowiedzieliśmy się, że sa różne myślenia, ale ja nie wiem czy to już wszystkie. Możemy o tym jeszcze pomyśleć.

Dziękuję wam za udział w tych zajęciach, ja też się dużo dowiedziałam i było mi miło z wami rozmawiać. Dzięki wam przychodzą mi do głowy nowe pomysły. Mogę, więc powiedzieć, że dzięki wam myślę.

\section{Pamiętnik filozoficzny ${ }^{31}$}

Ostatnio na zajęciach filozofii zastanawialiśmy się nad sprawą myślenia. Interesowało nas - czy chłopcy i dziewczynki myślą tak samo i jak to się dzieje, że myślimy? Dużo o tym rozmawialiśmy, aż pojawiło się takie zdanie:

\section{- Myśleć można tylko o tym, co się zna.}

Na filozofii można nie zgadzać się z tym, co ktoś mówi, więc szybko ktoś powiedział, że:

- Przecież jak się coś wymyśla, to właśnie myśli się o tym, czego się nie zna.

To są bardzo interesujące zdania i warto jeszcze się nad nimi zastanowić.

Zauważyliśmy, że skoro wymyślanie jest myśleniem, to może są jeszcze inne rodzaje myślenia, tylko trzeba się jeszcze pozastanawiać. To była ciekawa rozmowa, podczas której powstał ładny rysunek.

${ }^{30}$ To jest bardzo istotny moment zajęć, powinny być w niego zaangażowane dzieci. Mają wtedy okazje do ogarnięcia tego, w czym uczestniczyły i do odczucia odpowiedzialności za swoją pracę.

${ }^{31}$ Ponieważ efekty takich zajęć są bardzo ulotne, proponuję założenie teczki i umieszczanie w niej różnorodnych materiałów: rysunków dzieci, notatek czy przygotowanych po zajęciach kart. Oto przykład karty z tworzonego w czasie roku szkolnego Pamiętnika filozoficznego. 
ANNA BUŁA

\section{Developing the critical thinking y philosophizing with the youngest pupils}

In the light of the international school achievements research results, polish pupils are the ones to perform the worst when thinking abilities are concerned. Experts criticise polish educational establishments for the quality of teaching as well as for neglecting the important areas of children development, from which criticism derives the research of the effective methods of fixing this situation. The Mathew Lipman's educational program, whose principle is to develop thinking abilities and which constitutes almost ready teaching tool, is present among them. The project waits to be implemented in the polish educational system. One of the most crucial concepts of this program is the critical thinking. While there is no doubt about its value in the modern, democratic world, it is not yet generally believed that this could be tought at school. The article also presented an example of classes in the group of primary school children, who begin to work on their thinking. Because one of the conditions of the development of critical thinking is thinking about thinking. 